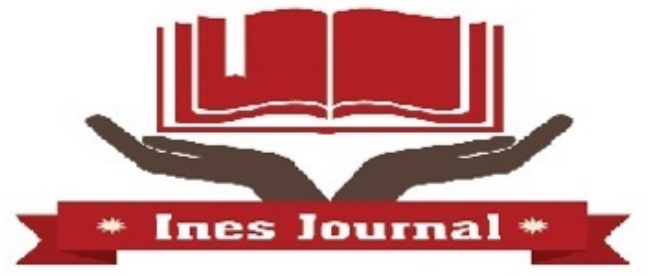

Yıl: 5, Sayı: 14, Mart 2018, s. 1-18

\section{INESJOURNAL}

ULUSLARARASI EĞITTIM BİLIMLERİ DERGİSİ THE JOURNAL OF INTERNATIONAL EDUCATION SCIENCE

\author{
Hilmi KARACA ${ }^{1}$, İbrahim YALÇINKAYA ${ }^{2}$
}

\title{
ORTAOKUL CEBİR ÖĞRENME ALANI TUTUM ÖLÇEĞİ (CTÖ) ${ }^{3}$
}

\section{Özet}

$\mathrm{Bu}$ çalışmada ortaokul öğrencilerinin matematik dersinde cebir öğrenme alanına yönelik tutumlarının ölçülebilmesi için geçerli ve güvenilir bir ölçek geliştirilmesi amaçlanmıştır. Geliştirilen ölçek 5'li likert tipi bir tutum ölçeğidir. Araştırma, 2014-2015 Eğitim Öğretim Yılı içerisinde yapılmıştır. Çalışmalar beş farklı devlet ortaokulundan 336 öğrenci ile yürütülmüştür. Yapı geçerliği için yapılan açımlayıcı faktör analizi (AFA) ve doğrulayıcı faktör analizi (DFA) uygulanmıştır. CTÖ (Cebir Öğrenme Alanı Tutum Ölçeği) açımlayıcı faktör analizi öncesi cronbach alpha güvenirlik katsayısı ,96, analiz sonrasında ise, 90 olarak hesaplanmıştır. Ölçek verilerinin KMO testi değeri ,949 ve Bartlett testi 9556,76 $(\mathrm{p}<0,05)$ olarak bulunmuştur. Elde edilen 28 maddelik CTÖ dört faktörden oluşmaktadır. Uyum indeksleri $\chi^{2} / \mathrm{df}=1,83$; GFI $=, 88$; $\mathrm{AGFI}=, 86$; NFI $=, 95 ; \mathrm{NNFI}=, 97$; CFI $=, 98$; RMSEA $=, 05$; $\mathrm{SRMR}=, 049$ olarak hesaplanmıştır. Araştırma sonucunda geçerli ve güvenilir bir tutum ölçeği geliştirilmiştir.

Anahtar Kelimeler: Matematik eğitimi, cebir öğrenme alanı, tutum, ölçek geliştirme, uyum modeli

\section{SECONDARY SCHOOL ALGEBRA LEARNING FIELD ATTITUDE SCALE (AAS)}

\section{Abstract}

In this study, it was aimed to develop a valid and reliable scale in order to measure the attitudes of secondary school students towards algebra learning in mathematics lessons. The developed scale is a 5 point likert type attitude scale. The research was carried out 2014-2015 education year. The work was conducted with 336 students. For construct validity, Explicit Factor Analysis (EFA) and Confirmatory Factor Analysis (CFA) were applied. Cronbach alpha reliability coefficient of the Algebra Learning Area Attitude Scale (AAS) was ,96 before Confirmatory Factor Analysis and ,90 after the analysis. KMO test value of scale data was found ,949 and Bartlett test was found 9556,76 $(\mathrm{p}<, 05)$. The 28-item AAS obtained consists of four factors. The fit indices were calculated as $\chi^{2} / \mathrm{df}=1,83, \mathrm{GFI}=, 88, \mathrm{AGFI}=, 86$, $\mathrm{NFI}=, 95, \mathrm{NNFI}=, 97, \mathrm{CFI}=, 98 \mathrm{RMSEA}=, 05$ and $\mathrm{SRMR}=, 049$. As a result of the research, a valid and reliable attitude scale was developed.

Keywords: Education of mathematics, attitude, scale development, the field of learning algebra, fit model

\footnotetext{
${ }^{1}$ Arş. Gör., Aksaray Üniversitesi, Eğitim Fakültesi, Matematik Eğitimi ABD, hilmikaraca@aksaray.edu.tr

${ }^{2}$ Prof. Dr., Necmettin Erbakan Üniversitesi, Fen Fakültesi, Uygulamalı Matematik ABD, iyalcinkaya@konya.edu.tr

${ }^{3}$ Bu çalışma, Hilmi KARACA tarafından Necmettin Erbakan Üniversitesi, Eğitim Bilimleri Enstitüsü'nde Prof. Dr. İbrahim YALÇINKAYA danışmanlığında yürütülen Ortaokul Öğrencilerinin Cebir Öğrenme Alanına Yönelik Tutumları (Ölçek Geliştirme Çalışması) başlıklı yüksek lisans tezinden üretilmiştir.
} 


\section{GİRIŞ}

Matematik, insanın düşünme becerilerine olan katkısı ile bilimsel ve teknolojik alanlarda gelişmelerin bir anahtarı olmuştur. Matematikte yaşanan geliş̧melerin yansıması fazla geçmeden bu alanlarda da hissedilir. Genel olarak bilimin gelişiminde önemli bir disiplin olan matematik, kendi içinde sayılar, geometri, ölçme, olasılık ve cebir öğrenme alanlarına ayrılmıştır (MEB, 2009; Van De Walle, John A., Karp, Karen S. ve Bay-Williams, Jennifer M., 2012). Her bir öğrenme alanı standardı, bütün sınıf düzeyleri gruplarına uygulanabilir amaçların küçük bir kümesini içermektedir. Sonra her bir sınıf düzeyi grubu, öğrencilerin bilmesi gereken özel kazanımlar sağlamaktadır (Van De Walle vd., 2012, s. 3). Bu alanların en önemlilerinden biri cebir öğrenme alanıdır.

Cebir, bilinmeyen değerlerin sembol veya harflerle belirtilmesiyle kurulan denklemler sayesinde bulunması, bazen de birkaç bilinmeyen arasındaki ilişkiler kurulmasını kapsar (Yenilmez ve Avcu, 2009; Kabayel ve Tanışlı, 2010). Ayrıca cebir, matematiksel muhakeme, sembolleri anlamlandırma ve matematiksel akıl yürütme gibi temel kavramları bünyesinde barındırmaktadır. $\mathrm{Bu}$ da matematiksel düşünme, muhakeme yeteneği ve problem çözme becerisinin gelişmesinde önemli olanaklar sunar (Yenilmez ve Avcu, 2009, Van De Walle vd., 2012; Kabayel ve Tanışl1, 2010). Cebir alt öğrenme alanları; cebirsel ifadeler, denklemler, örüntüler ve ilişkiler, eşitsizlikler, eşitlik ve denklemdir (MEB, 2009).

Ulusal ve uluslararası matematik eğitimi programlarında cebir eğitimi ortaokul kademesinde verilmektedir. Cebir yapısı itibariyle genellemeler ve soyutlamalar içerdiğinden ilkokul kademesinde bazı örneklerle sınırlı sezdirmeler dışında verilmemektedir. Ortaokul seviyesinde de sınıf düzeyine bağlı olarak sarmal bir şekilde verilmektedir. Cebir alt öğrenme alanları sınıf düzeylerine göre içerikleri genişleyerek ilerlemektedir. İçerik olarak da cebir ileri matematiksel konulara temel oluşturmaktadır. $\mathrm{Bu}$ da cebir öğrenme alanının önemini arttırmaktadır.

Cebirle ilgili kazanımlar işlenirken ortak ve alana özgü becerilerin, duyuşsal özelliklerin, öz düzenleme ve psikomotor becerilerin kazandırılmasına önem verilmelidir (MEB, 2009, s.99). Matematik üzerinde etkili olan duyuşsal kavramlardan bir tanesi de tutumdur. İnceoğlu'na göre (2004), tutum, bireyin kendine ya da çevresindeki herhangi bir nesne, toplumsal konu ya da olaya karşı deneyim, bilgi, duygu ve motivasyonuna dayanarak örgütlediği zihinsel, duygusal ve davranışsal bir tepki, ön eğilimidir. Kağıtçıbaşı (2005) bir tutumun meydana getirdiği sadece bir davranış eğilimi ya da sadece bir duygu değil, düşünce-duygu-davranış eğilimi bütünleşmesidir. Verilen tanımlar tutumun öğretim aşamasında da etkili olabileceğini işaret etmektedir. $\mathrm{Bu}$ aşamada öğrencinin öğrenim öncesi ve sonrası durumlardaki tutumu öğrenci başarısını etkilemektedir. Sonuç olarak öğrencinin cebire karşı sahip olduğu tutum da gerek cebir öğrenme alanındaki başarısını gerekse matematiksel düşünme, muhakeme yeteneği, problem çözme becerisi gibi matematik eğitiminde temel kavramlara yönelik davranışlarını etkileyecektir.

Matematik ve tutum ölçeği ile ilgili yapılan literatür taraması sonucu matematik (Önal, 2013; Duatepe ve Çilesiz, 1999) ve matematiğe ait alt konulara yönelik (Doğan ve Başokçu, 2010) farklı tutum ölçekleri bulunmaktadır. Geliştirilen tutum ölçeği geliştirme çalışmalarına örnek olarak; Matematiğe Yönelik Tutum Ölçeği (MYTÖ) (Önal, 2013), Matematik Başarı Yönelimleri Ölçeği (MBYÖ) (İlhan ve Çetin, 2014), Attitude Towards Mathematics Scales (Matematiğe Karşı Tutum Ölçeği) (ATMS) (Palacios, Arias ve Arias, 2014), FeTeMM Farkındalık Ölçeği (FFÖ) (Buyruk ve Korkmaz, 2016), , Öğretmen Adayları İçin Geometrik 
Cisimler Konusuna Yönelik Tutum Ölçeği Geliştirme Geçerlik ve Güvenirlik Çalışması (Gürefe ve Kan, 2013) verilebilir.

Matematiğe ait öğrenme alanlarını temel alan tutum ölçeklerine örnek olarak Geometriye Yönelik Bir Tutum Ölçeği (Bulut, Ekici, İşeri ve Helvac1, 2002) ve Olasılık Tutum Ölçeği (Bulut, Yetkin ve Kazak, 2002) verilebilir. Ancak cebir öğrenme alanı ile doğrudan ilgili tutum ölçeğinin olmayışı bu çalışmanın yapılma sebebini oluşturmuştur. Bu amaçla matematiğin önemli bir öğrenme alanı olan cebir öğrenme alanına yönelik tutum ölçeği geliştirilmiştir.

$\mathrm{Bu}$ bilgiler çerçevesinde çalışmanın temel amac1, ortaokul kademesinde eğitim gören 6,7 ve 8. sınıf öğrencilerinin cebir öğrenme alanına ve cebir öğrenme alanına ait alt öğrenme alanlarına yönelik tutumlarını ölçmeyi amaçlayan geçerli ve güvenilir bir ölçek geliştirmektir. Çalışmanın ortaokul 5. sınıf seviyesindeki öğrencilere uygulanmama sebebi, Türkiye'de matematik eğitiminde cebir öğretimi 6. sınıftan itibaren başlıyor olmasıdır. Yapılan bu çalışma ile ortaokulda cebir dersi alan öğrencilerin cebire karşı tutumlarını belirleyerek hem öğrenci için hem de diğer değişkenler açısından öğrencinin sahip olduğu özelliklerin ve uygun ders işleniş ve yaklaşımlarının belirlenebilmesi amaçlanmaktadır.

\section{YÖNTEM}

\section{Araștırmanın Modeli}

Bu çalışmada tarama modeli kullanılmıştır. Cohen'e (2007) göre tarama çalışmaları tutum çalışmaları gibi geniş katılımlı örnekleme ihtiyaç duyulan çalışmalar için kullanılabilecek ideal araştırma yöntemidir (Akt: Gürefe ve Kan, 2013).

\section{Evren-Örneklem Grubu}

Araştırmanın evreni Türkiye'de bulunan ortaokul öğrencileridir. Araştırmanın örneklemi, 2014-2015 eğitim-öğretim yılında basit seçkisiz olarak belirlenmiş 5 farklı resmi okulda, ortaokul 6, 7 ve 8 . sınıfta öğrenim gören öğrenciler arasından yine seçkisiz olarak belirlenmiş olan toplam 336 öğrenciden oluşmaktadır. Örneklemin 178 (\%53)'i kız, 158 (\%47)'i erkek öğrencidir. Öğrencilerin 143 'ü 6. sınıf $(42,6), 92$ 'si 7. sınıf $(\% 27,4)$ ve 101'i 8. sinıf $(\% 30,1)$ öğrencisidir.

Faktör analizinde önemli bir tartışma konusu, faktör analizi yapmak için yeterli sayılacak örneklem sayısıdır. Örneklem sayısı için Nunally (1978) madde sayısının 10 katını önerirken, Kass ve Tinsley (1979), eğer örneklem sayısı 300'ün altındaysa madde sayısının 5 ila 10 katı olması gerektiğini, örneklem sayısı 300'ü geçtiğinde, (madde sayısına orandan bağımsız bir biçimde), kararlı sonuçlara ulaşıldığını belirtmektedir (Akt: Can, 2013). Bu veriler 1şığında 54 maddelik taslak ölçeğin uygulandığ 336 kişilik örneklemin yeterli büyüklüğe sahip olduğuna karar verilmiştir.

\section{Veri Toplama Aracı}

Taslak Ölçek Madde Havuzunun Oluşturulması: Veri toplama aracının geliştirilmesi için öncelikle alan yazın taraması yapılmıştır. Özellikle cebir öğrenme alanına yönelik MEB'e ait kaynaklar incelenerek cebirin hem öğrenme alanına yönelik hem de alt öğrenme alanlarına yönelik kazanım temelli maddelerin oluşturulmasına dikkat edilmiştir. Uzman görüşleri ışığında, 54 maddeden oluşan 5 maddelik Likert tipi ölçek formu hazırlanmıştır. Ölçek maddeleri hazırlanırken kazanıma, kavrama veya konuya yönelik sahip olunan tutumu ölçmesi hedeflenen tutum cümlelerinin bilişsel, duyuşsal, psikomotor içerikli olarak yazılmasına dikkat 
edilmiştir. Ölçek maddeleri var olan durumu ortaya çıkarmayı amaçlayacak şekilde hazırlanmaya özen göstermiştir. Ölçekteki maddeler "Kesinlikle Katılıyorum", "Katılıyorum", "Kararsızım", "Katılmıyorum", "Hiç Katılmıyorum" şeklinde belirtilen 5'li Likert tipi derecelemeye sahip olacak şekilde düzenlenmiştir.

Maddeler geniş zamanlı fiillerle yazılmıştır. Maddelerin kolay anlaşılır ve cevaplayanı sıkmayacak şekilde sade bir dil kullanılarak yazılmasına özen gösterilmiştir.

Uzman Görüşüne Başvurma: Kapsam geçerliğinde (Büyüköztürk vd., 2014), ölçme araçlarının ölçülmek istenen davranışları sorgulamada yeterli olması beklenir. Bu yeterliği kapsam geçerliği ile sağlanması amaçlanmıştır. Kapsam geçerliği için uzman görüşüne başvurulmuştur. Bu amaçla maddelerin yazılmasında ve taslak ölçeğin oluşturulması sürecinde matematik eğitimi alanında uzman 3 akademisyen ve 2 matematik öğretmenin görüşü alınmıştır. Yapılan dönütlere göre maddelerde ve ölçek yönergesinde düzeltmeler yapılmıştır. Elde edilen 54 maddelik taslak ölçek ile uygulama aşamasında karşılaşılabilecek olası anlam ve şekil hatalarını belirlemek amaçlı ön uygulama yapılarak taslak ölçek test edilmiştir.

Ön Uygulama Aşaması: Uzmanların görüş ve önerileri doğrultusunda hazırlanmış olan taslak Cebir Tutum Ölçeği (CTÖ)'nin ölçek formu 25 öğrenciden oluşan bir gruba uygulanmıştır. Uygulama sırasında öğrencilerin anlamakta güçlük çektikleri ölçek yönergesinin bazı kısımları ve maddeler belirlenmiştir. Belirlenen bu maddeler tekrar incelenerek gerekli görülen düzeltmeler yapılmıştır

Ölçeğin Uygulanması: Bu aşamada hazırlanan 54 maddelik taslak ölçek seçkisiz olarak belirlenmiş olan 336 öğrenciye uygulanmıştır. Uygulama tüm sınıf seviyelerinde cebir kazanımlarının tamamlanmış olduğu 2015 Mayıs ayında yapılmıştır.

\section{Veri Analizi}

Araştırmada veri toplama aracıyla toplanan verilerin analizine geçmeden önce, uygulanan ölçme araçları 1'den 336'ya kadar numaralandırılmıştır. Numaralandırma işleminden sonra verilen numaralara uygun olarak veriler bilgisayar ortamına aktarılmıştır. Daha sonra CTÖ'nün ve alt boyutların geçerlik ve güvenirliği hesaplanmıştır. Ayrıca yüzde, aritmetik ortalama, standart sapma frekans analizi yapılmıştır. Açımlayıcı ve doğrulayıcı faktör analizi sonucunda elde edilen 28 maddenin maddeler ve boyutlar arası model uyumu incelenmiştir. Yapılan istatistiksel çözümlemeler için anlamlılık düzeyi ,05 olarak belirlenmiştir.

Faktör analizi aşamasında ölçekteki maddeler "Kesinlikle Katılıyorum", "Katılıyorum", "Kararsızım", "Katılmıyorum", "Hiç Katılmıyorum" şeklinde belirtilen 5'li Likert tipi dereceleme ölçeğinde düzenlenmiştir. Olumlu maddeler "Kesinlikle Katılıyorum" kategorisinden başlayarak sırayla 5, 4, 3, 2, 1 olarak puanlanırken, olumsuz maddeler ise "Hiç Katılmıyorum" kategorisinden başlayarak 1, 2, 3, 4, 5 olarak puanlanmıştır (Tablo 1).

Tablo 1. Faktör analizi puanlama aralığ

\begin{tabular}{lll}
\hline Seçenekler & Verilen Puan & Puan Aralı̆̆ \\
\hline Kesinlikle Katılıyorum & 5 & $4,20-5,00$ \\
Katılıyorum & 4 & $3,40-4,19$ \\
Kararsızım & 3 & $2,60-3,39$ \\
Katılmıyorum & 2 & $1,80-2,59$ \\
Hiç Katılmıyorum & 1 & $1,00-1,79$ \\
\hline
\end{tabular}


Ölçekte temel bileşenler yöntemiyle açımlayıcı faktör analizi (AFA) yapılmıştır. Yapılan bu çözümlemelere göre ölçek maddelerinin beklenilen alt boyutlarda yer alıp almadıklarının ve maddelerin başka faktörlerle binişik (birden çok faktöre yük verme) olup olmadıklarının belirlenmesi amacıyla madde faktör yükleri incelenmiştir. Daha sonra dört boyutlu olarak tasarlanan CTÖ için doğrulayıcı faktör analizi yapılmıştır.

Ölçeğin yap1 geçerliğine ilişkin değerlendirme yapmak amaciyla "Döndürülmüş Temel Bileşenler Analizi” ve ölçekten alınan toplam puanlarla ölçüt olarak alınan dört alt boyutun puanları arasındaki ilişkiyi ortaya koymak açısından Pearson Korelasyon Katsayıları hesaplanmıştır. Frekans, geçerlik, güvenirlik ve madde analizleri SPSS Programı ile yapılmıştır. Doğrulayıcı faktör analizinde Lisrel paket programı ile oluşturulan 4 faktörlü modelin uyumu incelenmiştir.

Güvenirlik Belirleme Aşamasında ölçeğin güvenirliği için madde toplam korelasyonlarından ve cronbach alpha katsayı değerlerinden faydalanılmıştır. cronbach alpha güvenirlik katsayıları ölçeğin her bir alt boyutu ve tamamı için hesaplanmıştır ve CTÖ’ye son hali verilmiştir (EK-1).

\section{BULGULAR}

Araştırmanın bulguları "Geçerlik ve Güvenirlik Analizi" ve "Uyum Modeli ve Doğrulayıcı Faktör Analizi” olmak üzere iki alt başlıkta verilmiştir.

\section{Ölçeğin Geçerlik ve Güvenirlik Analizi}

Yap1 geçerliği: testin ölçülmek istenen kavramı ne derece ölçebildiğini belirlemek için yapı geçerliği yapılmaktadır. Yapı geçerliğini ölçmek için iki yöntem, faktör analizi ve hipotez testi yapılmaktadır (Büyüköztürk vd., 2014). Bu çalışmada faktör analizlerinden yararlanılmıştır. Araştırmadan elde edilen verilerin analizleri sonucunda; örneklem oluşturma uygunluğu için yapılmış olan Kaiser-Meyer-Olkin değeri ,946 olarak elde edilmiştir. Bartlett Bütünlük testide $p<0,05$ için anlamlı bulunmuştur. Ki-kare değeri 9556,759 ve standart sapması 1431 olarak elde edilmiştir. Ulaşılan bu değerler sonucunda, verilerin açımlayıcı faktör analizi için uygun olduğuna göstermektedir. Bu çalışmada faktörleştirme tekniği olarak temel bileşenler analizi kullanılmıştır.

Verilerin faktör analizine uygun olup olmadığına karar verilirken Kaiser-Meyer-Olkin (KMO) katsayısı ve Bartlett Sphericity testi kullanılmaktadır. Eğer KMO katsayısı ,60'dan yüksek ve Bartlett testi anlamlı çıkarsa, elde edilen verilerin faktör analizine uygun olduğu sonucuna varılabilir (Büyüköztürk vd., 2014).

Uygulanan 54 maddelik taslak CTÖ’nün cronbach alpha değeri ,96 olarak bulunmuş olup güvenirliğinin yeterli seviyede olduğuna karar verilmiştir.

Faktör sayısına karar verirken değerlendirilmesi gereken önemli husus, her bir faktörün toplam varyansa yaptığı katkıdır. Yüzde varyans değerine bakıldığında dört bileşenin önemli ölçüde varyansa katkı sağladığı görülmektedir. Araştırmanın faktör sayısının dört olarak sınanmasına karar verilmiştir. Açımlayıcı ve doğrulayıcı faktör analizi sonucu dört faktörde düşünülen ölçeğin varyansa yaptığı katkının \% 50,811 olduğu görülmektedir (Tablo 2). 
Tablo 2. CTÖ'nün faktör analizi sonrası açıklanan toplam varyans tablosu

\begin{tabular}{cccccccccc}
\multicolumn{10}{c}{ Açıklanan Toplam Varyans } \\
\hline Faktörr & \multicolumn{2}{c}{ Başlangıç Öz Değerler } & \multicolumn{2}{c}{$\begin{array}{c}\text { Extraction Sums of Squared } \\
\text { Loadings }\end{array}$} & \multicolumn{2}{c}{$\begin{array}{c}\text { Rotation Sums of Squared } \\
\text { Loadings }\end{array}$} \\
\cline { 3 - 10 } Total & $\begin{array}{c}\text { Varyans } \\
\text { \% }\end{array}$ & $\begin{array}{c}\text { Birikimli } \\
\text { \% }\end{array}$ & Top & Varyans \% & Birikimli \% & Top & Varyans \% & Birikimli \% \\
\hline 1 & 9,287 & 33,169 & 33,169 & 9,287 & 33,169 & 33,169 & 5,116 & 18,270 & 18,270 \\
2 & 2,121 & 7,575 & 40,744 & 2,121 & 7,575 & 40,744 & 4,359 & 15,567 & 33,837 \\
3 & 1,645 & 5,875 & 46,620 & 1,645 & 5,875 & 46,620 & 2,811 & 10,039 & 43,877 \\
4 & 1,174 & 4,191 & 50,811 & 1,174 & 4,191 & 50,811 & 1,942 & 6,934 & 50,811 \\
\hline
\end{tabular}

Extraction Method: Principal Component Analysis.

Yamaç birikinti grafiği (scree plot), faktör sayısına karar vermek amacıyla Cattell tarafından önerilen yardımcı bir grafiktir. Elde edilen yamaç birikinti grafiğinde de görüldüğg̈ gibi 4. faktörden sonra eğim plato yapmaktadır. (Şekil 1)

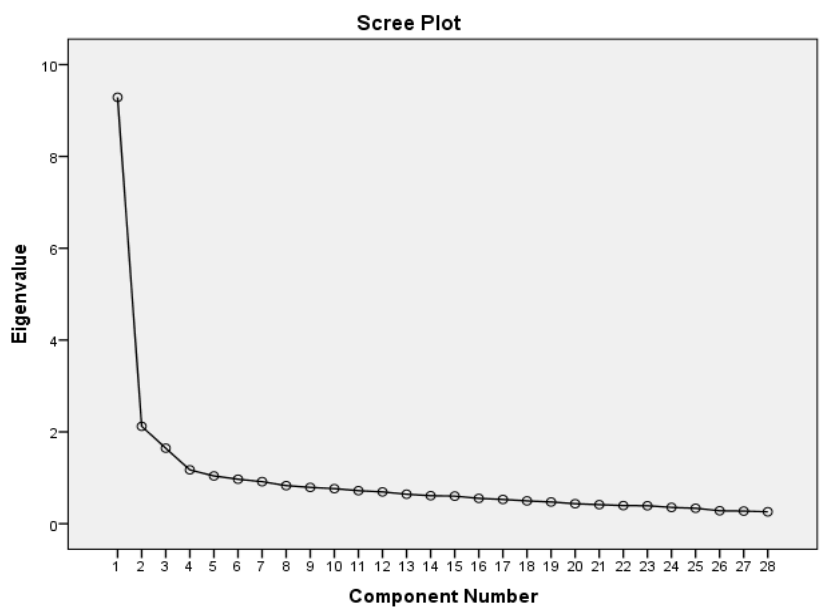

Şekil 1. Yeni taslak CTÖ yamaç-birikinti grafiği

Açımlayıcı ve doğrulayıcı faktör analizi sonrası maddelerin faktörlere göre yük değerleri ,365 ile,794 arasında değişmektedir. Maddelerin yük değerlerinin istenilen seviyelerde olduğu görülmüş̧ür. (Tablo 3).

Ölçeğin yapı geçerliliğini belirlemek için yapılan faktör analizi ile ölçekte yer alan maddelerin cebir öğrenme alanına yönelik tutum ile ilgili hangi faktörleri ölçtüğü ortaya çıkarılmıştır. Öncelikle veri yapısının faktör analizine uygun olup olmadığı KMO (Kaiser Meyer Olkin) testi ve Bartlett testi yöntemlerinden yararlanılarak kontrol edilmiştir. KMO testi değeri ,949 ve Bartlett testi 9556,759 ( $\mathrm{p}<0,05)$ olarak bulunmuştur. Bu iki değer faktör analizi yapmak için veri kümesinin uygun olduğunu göstermektedir.

Faktör sayısının belirlenmesinde öz değer (eigen value) istatistiği kullanılmıştır. Öz değer (eigen value) faktör yüklerinin kareleri toplamı olarak tanımlanabilir. Bir faktörün öz değeri, faktörle orijinal değişkenler arasındaki ilişkinin gücünü yansıtır. Öz değerler, faktörlerce açıklanan varyansı hesaplamada ve faktör sayısına karar vermede kullanılır (Çokluk vd., 2014, s.192). Faktör analizi ile madde yük değerleri düşük (0,30'un altında) ve binişik olan maddeler ölçekten çıkarılmıştır. 
Son durumda 4 faktörün açıkladığı toplam varyans miktarı \%50,811 olarak belirlenmiştir. Ölçek maddelerinin yük değerleri ,365 ile ,794 değerleri arasında değişmiştir.

Birinci faktör, bu faktörde yer alan maddelerin genel olarak ilgi ve yönelimleri yansıtttı̆ı için "İlgi Boyutu” olarak belirlenmiştir. İlgi boyutunun madde yük değerleri ,503 ile 691 değerleri arasındadır ve 11 maddeden oluşmaktadır (Tablo 3).

İkinci faktörü oluşturan maddeler davranışa yönelik olduğundan "Davranış Boyutu" olarak belirlenmiştir. Davranış boyutu madde yük değerleri ,365 ile ,734 değerleri arasındadır ve 9 maddeden oluşmaktadır (Tablo 3).

Üçüncü faktörü oluşturan maddeler duygu içeren maddeler olduğundan "Duyuşsal Boyut" olarak belirlenmiştir. Duyuşsal boyut madde yük değerleri ,501 ile ,692 değerleri arasındadır ve 5 maddeden oluşmaktadır (Tablo 3).

Dördüncü faktör ise endişe kayg1 ve korku ağırlıklı maddeler olduğundan "Kayg1 Boyutu" olarak belirlenmiştir. Kaygı boyutu madde yük değerleri ,668 ile ,794 değerleri arasındadır ve 3 maddeden oluşmaktadır (Tablo 3 ).

Tablo 3. Ölçekte kalan maddeler ve yük değerleri (Döndürülmüş Bileşenler Matris Değerleri)

\begin{tabular}{|c|c|c|c|c|c|}
\hline \multirow{2}{*}{\multicolumn{2}{|c|}{ Yeni Taslak Ölcek Sıra NumarasıTaslak Ölcek Sıra Numarası }} & \multicolumn{4}{|c|}{ Faktörler } \\
\hline & & 1 & 2 & 3 & 4 \\
\hline Z1 & S32 & 691 & & & \\
\hline $\mathrm{Z} 2$ & S45 & 651 & & & \\
\hline $\mathrm{Z} 3$ & S20 & 649 & & & \\
\hline $\mathrm{Z} 4$ & S47 & 643 & & & \\
\hline $\mathrm{Z} 5$ & S16 & 641 & & & \\
\hline Z6 & $\mathrm{S} 50$ & 640 & & & \\
\hline $\mathrm{Z7}$ & $\mathrm{S} 40$ & 612 & & & \\
\hline Z8 & S19 & 610 & & & \\
\hline Z9 & S14 & ,593 & & & \\
\hline $\mathrm{Z} 10$ & S46 & ,514 & & & \\
\hline Z11 & S39 & ,503 & & & \\
\hline Z12 & S37 & & ,734 & & \\
\hline Z13 & S28 & & 692 & & \\
\hline Z14 & S26 & & 684 & & \\
\hline Z15 & S48 & & 663 & & \\
\hline Z16 & S51 & & 636 & & \\
\hline Z17 & S30 & & 634 & & \\
\hline Z18 & S43 & & ,577 & & \\
\hline Z19 & S44 & & ,565 & & \\
\hline $\mathrm{Z} 20$ & S36 & & 365 & & \\
\hline $\mathrm{Z} 21$ & S05 & & & 692 & \\
\hline Z22 & S07 & & & 640 & \\
\hline Z23 & $\mathrm{S} 10$ & & & 605 & \\
\hline Z24 & S08 & & & 575 & \\
\hline Z25 & $\mathrm{S} 12$ & & & 501 & \\
\hline Z26 & S49 & & & & 794 \\
\hline Z27 & S25 & & & & 786 \\
\hline Z28 & S04 & & & & 668 \\
\hline
\end{tabular}


Yapılan analizler sonucunda elde edilen maddelerden oluşan ölçeğin cronbach alpha güvenirlik katsayısı ,90 olarak bulunmuştur. Ölçek boyutları için ayrı ayrı yapılan güvenirlik analizinde cronbach alpha değerleri sırasıyla ,88; ,88; ,72 ve ,66 olarak elde edilmiştir (Tablo 4).

Tablo 4. CTÖ’nün cronbach güvenirlik katsayıları

\begin{tabular}{cc}
\hline Boyutlar & Cronbach alpha Katsayısı \\
\hline İlgi Boyutu &, 88 \\
Davranışsal Boyut &, 88 \\
Duyuşsal Boyut &, 72 \\
Kaygı Boyutu &, 66 \\
Ölçek Geneli &, 90 \\
\hline
\end{tabular}

Analizler sonucunda elde edilen 28 maddelik ölçeğin maddeleri, faktör analizi sonucu elde edilen sıraya göre tekrardan numaralandırılarak, ölçeğin alt-üst gruplarına dayanan madde analizi yapılmıştır ve faktörlere dayalı bir model oluşturulup uyumu incelenmiştir. Alt-üst madde analizi sonucunda ölçekte yer alan 26,27 ve 28. maddeler, madde analizi sonuçlarına uygun olmadığ 1 yani ayırt edici özelliğinin bulunmadığ 1 tespit edilmiştir $(p<0,05)$. Belirtilen maddeler ayırt edici olmamasına rağmen faktör analizi sonucunda ölçek içerisinde bir faktör oluşturmaktadır ve bu maddelerin çıkarılması kapsam geçerliğini düşürecektir. Bu bilgilere dayanarak ve uzman görüşü de alınarak, bu maddelerin ölçekte kalmasının daha uygun olacağ 1 kararlaştırılmıştır ve ölçekte tutulmuştur (Tablo 5). 
Tablo 5. CTÖ alt-üst gruplarına dayanan madde analizi

\begin{tabular}{|c|c|c|c|c|c|c|c|c|c|c|}
\hline Maddeler & ALTÜST & $\mathbf{N}$ & Ortalama & $\begin{array}{c}\text { Standart } \\
\text { Sapma }\end{array}$ & $\begin{array}{c}\text { Ortalamanın } \\
\text { Standart } \\
\text { Hatası }\end{array}$ & $\mathbf{F}$ & Sig. & $\mathbf{t}$ & df & $\begin{array}{c}\text { Sig. } \\
(2- \\
\text { tailed) }\end{array}$ \\
\hline \multirow{2}{*}{ z01 } & ALT & 91 & 2,0879 & 1,16092 &, 12170 & \multirow{2}{*}{1,050} & \multirow{2}{*}{, 307} & \multirow{2}{*}{$-9,358$} & \multirow{2}{*}{180,000} & \multirow{2}{*}{, 000} \\
\hline & ÜST & 91 & 3,6044 & 1,02067 &, 10699 & & & & & \\
\hline \multirow{2}{*}{ z02 } & ALT & 91 & 1,8132 & 1,07406 & ,11259 & \multirow{2}{*}{,222 } & \multirow{2}{*}{,638 } & \multirow{2}{*}{$-12,394$} & \multirow{2}{*}{180,000} & \multirow{2}{*}{, 000} \\
\hline & ÜST & 91 & 3,7692 & 1,05490 & , 11058 & & & & & \\
\hline \multirow{2}{*}{ z03 } & ALT & 91 & 2,1868 & 1,17296 & ,12296 & \multirow{2}{*}{20,132} & \multirow{2}{*}{, 000} & & & \\
\hline & ÜST & 91 & 4,4945 &, 67286 &, 07054 & & & $-16,280$ & 180,000 &, 000 \\
\hline & ALT & 91 & 2,3077 & 1,27969 &, 13415 & & & & & \\
\hline z04 & ÜST & 91 & 4,3846 &, 82690 &, 08668 & 7,999 &, 000 & $-13,004$ & 180,000 & , 000 \\
\hline & ALT & 91 & 2,0879 & 1,19860 &, 12565 & & & & & \\
\hline z0s & ÜST & 91 & 4,1868 &, 82882 &, 08688 & 11,658 & ,001 & $-13,740$ & 180,000 & , 000 \\
\hline & ALT & 91 & 2,1648 & 1,17628 &, 12331 & & & & & \\
\hline z06 & ÜST & 91 & 4,1648 & 1,00293 &, 10514 & 5,020 & ,026 & $-12,342$ & 180,000 & , 000 \\
\hline 707 & ALT & 91 & 2,0110 & 1,12046 & , 11746 & & & & 180000 & \\
\hline $\mathrm{ZO} /$ & ÜST & 91 & 3,9341 & 1,16239 & , 12185 &, 254 & , 015 & $-11,363$ & 180,000 & , 000 \\
\hline & ALT & 91 & 2,3187 & 1,26385 & , 13249 & & & & & \\
\hline z08 & ÜST & 91 & 4,5824 &, 59751 &, 06264 & 53,458 & ,000 & $-15,447$ & 180,000 & ,000 \\
\hline 700 & ALT & 91 & 1,9560 & 1,17296 & , 12296 & 017 & 805 & 7280 & 180000 & 000 \\
\hline Z09 & ÜST & 91 & 3,1978 & 1,12763 &, 11821 & , 011 & , 895 & $-1,280$ & 180,000 & - \\
\hline & ALT & 91 & 2,4066 & 1,27347 & , 13350 & & & & & \\
\hline z10 & ÜST & 91 & 4,4396 &, 74846 &, 07846 & 26,945 & ,000 & $-13,129$ & 180,000 & , 000 \\
\hline & ALT & 91 & 2,4176 & 1,26549 & , 13266 & & & & & \\
\hline$z \|$ & ÜST & 91 & 4,2967 & ,92490 & ,09696 & 1,629 & , 001 & $-11,436$ & 180,000 & , 000 \\
\hline 712 & ALT & 91 & 3,0330 & 1,33708 & ,14016 & 67628 & 000 & -12169 & 180000 & 000 \\
\hline 212 & ÜST & 91 & 4,8571 &, 50709 & ,05316 & $0 /, 0<8$ & , & $-12,109$ & 180,000 &, 000 \\
\hline 713 & ALT & 91 & 2,4615 & 1,27635 &, 13380 & & 000 & -15474 & 180000 & 000 \\
\hline Z13 & ÜST & 91 & 4,7912 &, 65856 & ,06904 & , 583 &, 000 & $-15,4 / 4$ & 180,000 &, 000 \\
\hline & ALT & 91 & 2,4725 & 1,22330 & ,12824 & & & & & \\
\hline zl4 & ÜST & 91 & 4,5604 & ,97990 &, 10272 & 13,503 & , 000 & $-12,708$ & 180,000 & , 000 \\
\hline 715 & ALT & 91 & 2,4725 & 1,50806 & , 15809 & & & & 180000 & 000 \\
\hline Z15 & ÜST & 91 & 4,5495 & ,90999 & ,09539 & $43,9<3$ &, 000 & $-11,249$ & 180,000 & , 000 \\
\hline z16 & ALT & 91 & 2,0549 & 1,13884 &, 11938 & & & -17.060 & & \\
\hline z16 & ÜST & 91 & 4,4945 &, 75091 &, 07872 & 1,420 & , 001 & $-17,060$ & 180,000 & ,000 \\
\hline & ALT & 91 & 2,2637 & 1,23680 & , 12965 & & & & & \\
\hline $\mathrm{zl} 7$ & ÜST & 91 & 4,6593 &, 63630 &, 06670 & 251 & ,000 & $-16,430$ & 180,000 & ,000 \\
\hline 718 & ALT & 91 & 2,3736 & 1,32202 & , 13859 & & & & & \\
\hline z18 & ÜST & 91 & 4,7473 &, 64280 & 06738 & 63,192 &, 000 & $-15,403$ & 180,000 & , 000 \\
\hline 719 & ALT & 91 & 2,2308 & 1,20256 &, 12606 & 732 & 000 & -17813 & 180000 & 000 \\
\hline Z19 & ÜST & 91 & 4,7802 &, 64640 &, 06776 & 52,132 & , 000 & $-1 /, 813$ & 180,000 & , 000 \\
\hline 720 & ALT & 91 & 2,2198 & 1,38886 & , 14559 & 6.099 & 014 & -9.509 & 180000 & 000 \\
\hline $\mathrm{Z} \angle \mathrm{O}$ & ÜST & 91 & 4,0440 & 1,19175 & , 12493 & 0,099 & ,014 & $-9,509$ & 180,000 &, 000 \\
\hline 721 & ALT & 91 & 3,1868 & 1,35738 & , 14229 & & 000 & -8.862 & 180000 & 000 \\
\hline Z21 & ÜST & 91 & 4,6044 &, 69728 &, 07310 & 50,103 & ,000 & $-8,862$ & 180,000 & , 000 \\
\hline & ALT & 91 & 2,3187 & 1,33233 & , 13967 & & & & & \\
\hline z22 & ÜST & 91 & 4,1209 & 1,10388 &, 11572 & 6,288 & ,013 & $-9,936$ & 180,000 & , 000 \\
\hline 723 & ALT & 91 & 2,5165 & 1,42488 & , 14937 & & 000 & -9410 & 180000 & 000 \\
\hline ZL3 & ÜST & 91 & 4,2637 & 1,05235 &, 11032 & &, 000 & $-9,410$ & 180,000 & , 000 \\
\hline & ALT & 91 & 2,7143 & 1,37668 & , 14431 & 116 & & -13417 & 180000 & 000 \\
\hline Z24 & ÜST & 91 & 4,7802 &, 51212 &, 05369 & 2,116 & , 000 & $-13,417$ & 180,000 & , 000 \\
\hline 725 & ALT & 91 & 2,4615 & 1,19543 &, 12532 & & 000 & 13825 & 180000 & 000 \\
\hline ZZS & ÜST & 91 & 4,4725 &, 70460 & ,07386 & & , & $-15,825$ & 180,000 &, 000 \\
\hline 726 & ALT & 91 & 2,9231 & 1,52192 & , 15954 & & & & & \\
\hline Z26 & ÜST & 91 & 2,8681 & 1,45456 & , 15248 & & ,303 & 49 & 180,000 & ,804 \\
\hline 727 & ALT & 91 & 2,8242 & 1,51726 &, 15905 & & 078 & 257 & 180000 & 797 \\
\hline $\mathrm{Z} 21$ & ÜST & 91 & 2,7692 & 1,35873 & , 14243 & & , $0 / 8$ & , 251 & & \\
\hline & ALT & 91 & 2,7033 & 1,50181 &, 15743 & & 418 & & & 960 \\
\hline & ÜST & 91 & 2,6923 & 1,43521 & , 15045 & 000 & 410 & & 100,000 & - \\
\hline
\end{tabular}


Son durumda ölçekteki toplam madde sayısı 28'dir. Sonuç olarak ölçek, 4 faktör ve 28 maddeden oluşmaktadır. Bu ölçekten alınabilecek en düşük puan 28, en yüksek puan ise 140 'tir.

\section{Cebir Tutum Ölçeğine Ait Boyutların Uyum Modeli ve Doğrulayıcı Faktör Analizi}

Doğrulayıcı faktör analizi, önceden seçilen faktör modelinin veriye uyumunun sağlanıp sağlanmadığını değerlendirmek için kullanılan en etkili analizdir ve bu açıdan açımlayıcı faktör analizinden ciddi bir biçimde ayrılır. Doğrulayıcı faktör analizi ölçme araçlarının geliştirilmesi, düzenlenmesi ve yeniden gözden geçirilmesi çalışmalarında çok kullanışlıdır (Floyd ve Widaman, 1995; Çokluk vd., 2014).

Analizler sonucunda elde edilen 28 maddelik ölçeğin maddeleri, faktör analizi sonucu elde edilen sıraya göre tekrardan sıra numarası verilerek Lisrel ile model uyum testi yapılmıştır.

Tablo 6. Uyum modeli değerleri

\begin{tabular}{|c|c|c|c|c|}
\hline $\begin{array}{c}\text { Uyum } \\
\text { Kriteri } \\
\text { (Fit Criteria) }\end{array}$ & $\begin{array}{l}\text { Mükemmel Uyum } \\
\text { Değerleri } \\
\text { (Values of Good } \\
\text { Fit) (Çokluk vd., } \\
\text { 2014) } \\
\end{array}$ & $\begin{array}{c}\text { Kabul edilebilir } \\
\text { Uyum Değerleri } \\
\text { (Acceptable Fit } \\
\text { Values) (Çokluk } \\
\text { vd., 2014) } \\
\end{array}$ & $\begin{array}{c}\text { Ölçekten Elde } \\
\text { Edilen Uyum Değeri } \\
\text { (Fit Values } \\
\text { Obtained for the } \\
\text { Suggested Scale) } \\
\end{array}$ & $\begin{array}{l}\text { Uyum Derecesi } \\
\text { (Status of Fit) }\end{array}$ \\
\hline Ki-kare (p) & - & - & $631,97(\mathrm{p}=0,00)$ & $x_{-2}$ \\
\hline df & - & - & 344 & - \\
\hline $\mathrm{Ki}$-kare/df & $0 \leq \chi^{2} / \mathrm{df} \leq 2$ & $\chi^{2} / \mathrm{df} \leq 5$ & 1,83 & Mükemmel Uyum \\
\hline RMSEA & $0,00 \leq \mathrm{RMSEA} \leq 0,05$ & $\mathrm{RMSEA} \leq 0,08$ & 0,05 & Mükemmel Uyum \\
\hline RMR & $\mathbf{0 , 0 0} \leq \mathrm{RMR} \leq \mathbf{0 , 0 5}$ & $\mathbf{R M R} \leq \mathbf{0 , 0 8}$ & 0,092 & Zayıf Uyum \\
\hline SRMR & $0,00 \leq \mathrm{SRMR} \leq 0,05$ & $\mathrm{SRMR} \leq 0,08$ & 0,049 & Mükemmel Uyum \\
\hline GFI & $0,95 \leq \mathrm{GFI} \leq 1,00$ & GFI $\geq \mathbf{0 , 9 0}$ & $\mathbf{0 , 8 8}$ & Zayıf Uyum \\
\hline AGFI & $0,95 \leq \mathrm{AGFI} \leq 1,00$ & $\mathrm{AGFI} \geq 0,85$ & 0,86 & Kabul Edilebilir Uyum \\
\hline CFI & $0,95 \leq \mathrm{CFI} \leq 1,00$ & $\mathrm{CFI} \geq 0,90$ & 0,98 & Mükemmel Uyum \\
\hline NFI & $0,95 \leq \mathrm{NFI} \leq 1,00$ & $\mathrm{NFI} \geq 0,90$ & 0,95 & Mükemmel Uyum \\
\hline NNFI & $0,95 \leq \mathrm{NNFI} \leq 1,00$ & $\mathrm{NNFI} \geq 0,90$ & 0,97 & Mükemmel Uyum \\
\hline
\end{tabular}

Doğrulayıcı faktör analizi kapsamında, $\chi^{2} / \mathrm{df}$ (ki-kare/serbestlik derecesi) değeri 1,83 olarak bulunmuştur ki bu sonuç modelin mükemmel uyuma sahip olduğunu göstermektedir (Tablo 6). Bu değerin 2 veya altında bir değer olması modelin mükemmel bir model olduğunu 5 veya daha altında değer alması ise modelin kabul edilebilir bir uyum iyiliğine sahip olduğunu gösterir (Sümer, 2000).

Modelin RMSEA değeri ,05 olarak bulunmuştur (Tablo 6). RMSEA değerinin ,05'ten küçük olması mükemmel uyumu, ,08'den küçük olması ise iyi bir uyuma işaret eder (Jöreskog ve Sörbom, 2001; Çokluk vd., 2014). Bu çerçevede, yapılan analiz sonucu elde edilen uyum indeksi, modelin mükemmel uyuma sahip olduğunu ifade edebilir.

Modele ait GFI ve AGFI uyum indeksleri incelendiğinde, GFI'nın ,88, AGFI'nın ise ,86 olduğu görülmektedir (Tablo 6). GFI ve AGFI indekslerinin ,95'in üzerinde olması mükemmel uyuma karşılık gelmektedir. GFI' nın ,90'ın üzerinde olması ve AGFI' nın ,85 üzerinde olması kabul edilebilir uyuma karşılık gelmektedir (Çelik ve Yılmaz, 2014). Bu çerçevede, yapılan analiz için AGFI değeri kabul edilebilir uyuma ve GFI değeri zayıf uyuma karşıllk geldiği görülmektedir. Bunun sebebi örneklem büyüklüğünden kaynaklanabilmektedir. Çünkü bu indeksler göreceli olarak büyük bir örnekleme ihtiyaç duymaktadır (Çelik ve Yılmaz, 2014). Yapılan benzetim çalışmaları GFI ve AGFI'nın örneklem büyüklüğünden bağımsız olmadığını göstermiştir (Schermelleh-Engel and Moosbrugger, 2003; Akt: Çelik ve Yılmaz, 2013, s. 37 ). 
RMR uyum indeksinin ,92 ve SRMR uyum indeksinin ,049 olduğu görülmektedir (Tablo 6). RMR ve SRMR indekslerinin ,05'in altında olması mükemmel uyuma, ,08'in altında olması ise iyi uyuma ve ,10'un altında olması ise zayıf uyuma işarettir (Brown, 2006; Çokluk vd., 2014). Bu kapsamda elde edilen RMR değerinin zayıf uyuma, SRMR değerinin ise mükemmel uyuma karşılık geldiği söylenebilir. RMR gözlenen değerlerin varyans ve kovaryanslarının büyüklüğüne bağlıdır. Başka bir anlatımla değişkenlere ait ölçek verilmeksizin elde edilen bir RMR değerinin iyi veya kötü uyumu gösterip göstermediğini değerlendirmek olanaksızdır. Bu problemin çözümlenebilmesi için SRMR kullanılmaktadır (Schermelleh-Engel and Moosbrugger, 2003; Akt: Çelik ve Y1lmaz, 2013, s. 34).

Son olarak yapılan analizde NFI, NNFI ve CFI uyum indeksleri incelendiğinde, NFI'nın ,95 ; NNFI'nın ,97 ve CFI'nin ,98 değerine sahip olduğu görülmektedir (Tablo 6). NFI, NNFI ve CFI indekslerinin ,95'in üzerinde olması mükemmel uyuma, ,90'ın üzerinde olması iyi uyuma karşıllık gelmektedir (Sümer, 2000; Çokluk vd., 2014). Bu çerçevede, yapılan analiz için NFI, NNFI ve CFI değerlerinin mükemmel uyuma sahip oldukları görülmektedir.

Uygun bir ölçme modelinde faktör yüklerinin yüksek, hata varyanslarının düşük, faktör korelasyonlarının ,85'den küçük olması beklenir. Faktör korelasyonlarının ,85'i geçmesi ise aslında daha az faktörle model veri uyumunun sağlanabileceği ve varlı̆̆ iddia edilen faktörlerin birbirinden ayrı kavramlar olmadıkları düşünülür (Sümer, 2000; Çokluk vd., 2014; Çelik ve Yılmaz, 2013). Elde edilen faktör korelasyonları ,85 'den küçüktür. Bu sebeple belirlenen faktörlerde bir işlem yapılmadan başlı başına bir faktör olarak değerlendirilmiştir. 


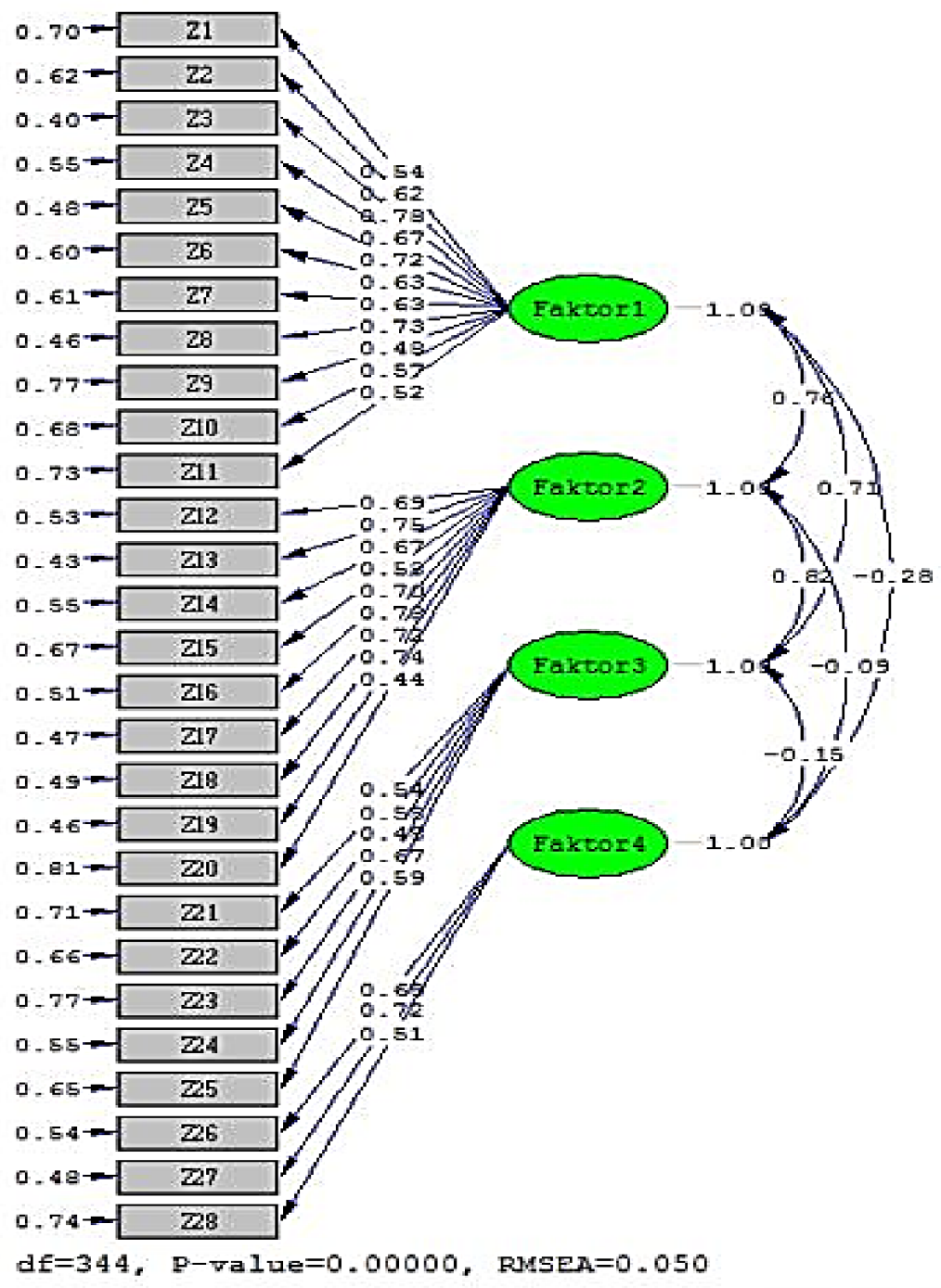

Şekil 2. Uyum modeli standartlaştırılmış çözüm bulguları 


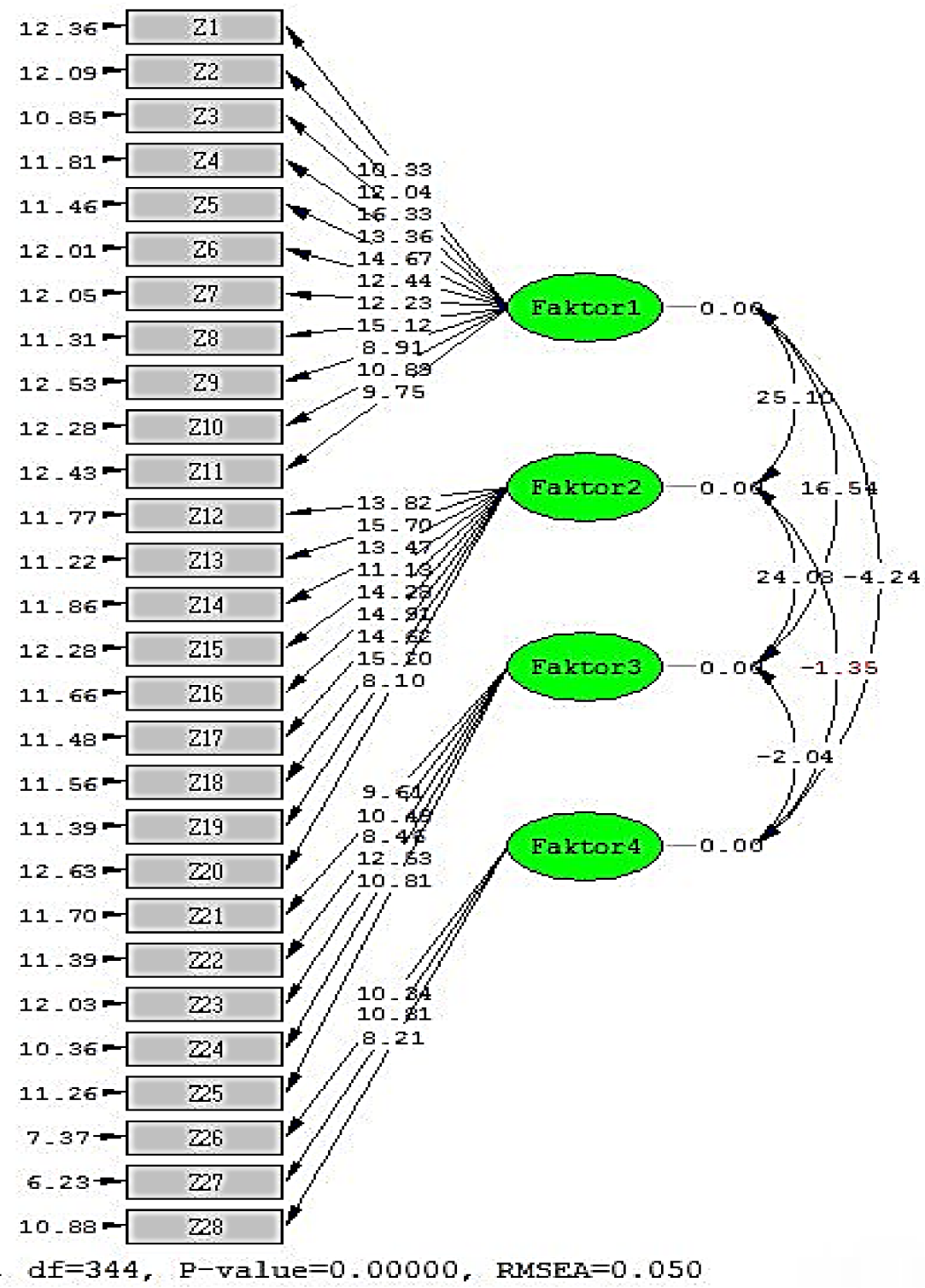

Chi-Square=631.97, df=344, P-value=0.00000, FMSER=0.050

Şekil 3. Uyum modeli t-değeri bulgularl

TARTIŞMA ve SONUÇ

\section{Geçerlilik ve Güvenirlik Analizi Sonuçları}

Analiz öncesinde yapılan güvenirlik analizinde, 54 maddelik taslak CTÖ'nin cronbach alpha değeri ,96 olarak bulunmuştur. Analizler sonucu ulaşılan 28 maddelik CTÖ'nün son hali için yapılan güvenirlik analizinde ise cronbach alpha değeri ,90 olarak bulunmuştur.

Ölçek boyutları için ayrı ayrı yapılan güvenirlik analizinde cronbach alpha değerleri birinci boyutta , 88 , ikinci boyutta, 88 , üçüncü boyutta, 72 ve dördüncü boyutta ,66 olarak elde edilmiştir. Ulaşılan bu değerler istenilen seviyede olduğu görülmüştür. Elde edilen cronbach alpha değerleri analiz öncesinde, sonrasında ve ölçeğin alt boyutlarında güvenirliğinin yüksek olduğunu göstermektedir.

Alt-üst geçerlik analizi sonucunda ölçekte yer alan 26, 27 ve 28. maddeler, madde analizi sonuçlarına uygun olmadığı yani ayırt edici özelliğinin bulunmadığı tespit edilmiştir $(p<0,05)$. Fakat uzman görüşü de alınarak, bu maddelerin ölçekte kalmasının daha uygun olacağı kararı 
alınmıştır ve ölçekte tutulmuştur. Ayrıca ölçek için yapılan faktör analizi maddelerin homojenliğinin sağladığından ölçeğin güvenirliğine katkı sağlamaktadır (Tavşancıl, 2010).

\section{Faktör Analizi Sonuçları}

Faktör analizi sonucunda 56 maddelik taslak tutum ölçeği 28 maddeye indirgenmiştir. Analiz sonrasında ölçek 4 boyuttan oluşmaktadır. Bunlar ilgi boyutu, davranışsal boyut, duygu boyutu ve kaygı boyutudur. İlgi boyutu maddeleri öğrencilerin cebire karşı olumlu veya olumsuz ilgilerini yansıtacak bir yapıda şekil almıştır. Davranış boyutundaki maddeler öğrencilerin cebir sorularına karşı nasıl bir yönelim gösterdiklerini yansıtacak şekilde oluşmuştur. Duygu boyutu, cebirin öğrenciler üzerinde nasıl bir etki bıraktığını ve öğrencilerin cebire duyuşsal olarak yaklaşımını yansıtmaktadır. Kaygı boyutunda ise öğrencilerin cebire karşı kaygılarını belirleyecek bir içeriğe sahiptir.

\section{Cebir Tutum Ölçeği Uyum Modeli Sonuçları}

Faktör analizi ile 28 maddeye indirilen ölçek, doğrulayıcı faktör analizi ile kurulan modelin verilerle uyumu incelenmiştir.

Doğrulayıcı faktör analizi kapsamında, $\chi^{2} / \mathrm{df}$ (ki-kare/serbestlik derecesi) değeri 1,83 olarak bulunmuştur ki bu sonuç modelin mükemmel uyuma sahip olduğunu göstermektedir. Modelin RMSEA değeri ,05 olarak bulunmuştur. RMSEA değerinin ,05 veya ,05'ten küçük olması mükemmel uyumu, ,08'den küçük olas1 ise iyi bir uyuma işaret eder. GFI'nın ,88, AGFI'nın ise ,86 olduğu görülmektedir. GFI değeri zayıf uyuma, AGFI değeri kabul edilebilir uyuma karşılık geldiği görülmektedir. Bunun sebebi örneklem büyüklügünün bu indeksler için yeterli büyüklükte olmamasından kaynaklanabilmektedir.

RMR uyum indeksinin ,92 ve SRMR uyum indeksinin ,049 olduğu görülmektedir. Elde edilen RMR değerinin zayıf uyuma, SRMR değerinin ise mükemmel uyuma karşıllk geldiği söylenebilir.

Son olarak yapılan analizde NFI, NNFI ve CFI uyum indeksleri incelendiğinde, NFI'nın ,95, NNFI'nın ,97 ve CFI'nin ,98 değerine sahip olduğu görülmektedir. NFI, NNFI ve CFI değerlerinin mükemmel uyuma sahip oldukları görülmektedir.

Elde edilen CTÖ ile öğrencilerin cebir öğrenme alanına karşı tutumları ölçülebileceği gibi sonuçları ile de bu tutumları geliştirebilecek çalışmalar yapılabilir. Ayrıca cebir tutumunun cinsiyet ve sınıf düzeyi gibi açısından değerlendirmeler yapılabilir.

\section{KAYNAKÇA}

Akkan, Yaşar, Baki, Adnan ve Çakıroğlu, Ünal (2011). Aritmetik İle Cebir Arasındaki Farkl111klar: Cebir Öncesinin Önemi. Elementary Education Online, 10(3), 812-823.

Aşkar, Petek (1986). Matematik Dersine Yönelik Tutumu Ölçen Likert Tipi Bir Ölçeğin Geliştirilmesi. Ĕgitim ve Bilim, 11 (62), 31-36.

Baykul, Yaşar (2010). Eğitimde ve Psikolojide Ölçme Klasik Test Teorisi ve Uygulaması (2. Bask1). Ankara: Pegem Akademi.

Bulut, Safure, Ekici, Celil, İşeri, Aykut İ. Ve Helvac1, Ebru (2002). Geometriye Yönelik Bir Tutum Ölçeği, Ĕ̌itim ve Bilim,27(2), 3-7. 
Bulut, Safure, Yetkin, Elif İ. ve Kazak, Sibel (2002). Matematik Öğretmen Adaylarının Olasılık Başarısı, Olasılık ve Matematiğe Yönelik Tutumlarının Cinsiyete Göre İncelenmesi, Hacettepe Üniversitesi Eğitim Fakültesi Dergisi, 22, 21-28.

Buyruk; Büşra ve Korkmaz, Özgen (2016). FeTeMM Farkındalık Ölçeği (FFÖ): Geçerlik ve Güvenirlik Çalışması. Türk Fen Eğitimi Dergisi 13(2), 61-76.

Büyüköztürk, Şener, Çokluk, Ömay ve Köklü, Nilgün (2014). Sosyal Bilimlerde İstatistik (15. Bask1). Ankara: Pegem Akademi.

Can, Abdullah (2013). SPSS ile Bilimsel Araştırma Sürecinde Nicel Veri Analizi (1. Baskı). Ankara: Pegem Akademi.

Çanakçı, Orhan ve Özdemir, Ahmet Şükrü (2011). Matematik Problemi Çözme Tutum Ölçeğinin Geliştirilmesi. AIBÜ, Eğitim Fakültesi Dergisi, 11(1), 119-136.

Çelik, H. Eray ve Yılmaz, Veysel (2013). Lisrel 9,1 ile Yapısal Eşitlik Modellemesi Temel Kavramlar Uygulamalar Programlama (2. Bask1). Ankara: Anı Yayınc1lık.

Çokluk, Ömay, Şekercioğlu, Güçlü ve Büyüköztürk, Şener (2014). Sosyal Bilimler Iç̧in Çok Değisskenli Istatistik SPSS ve LISREL Uygulamaları (3. Baskı). Ankara: Pegem Akademi.

Demir, Cennet Göloğlu ve Çetin, Şaban (2012). Matematik Öğretimi Tutum Ölçeğinin Geliştirilmesi. Gazi Üniversitesi Endüstriyel Sanatlar Eğitim Fakültesi Dergisi, 29, 5965 .

Doğan, Nuri ve Başokçu, T. Oğuz (2010). İstatistik Tutum Ölçeği İçin Uygulanan Faktör Analizi ve Aşamalı Kümeleme Analizi Sonuçlarının Karşılaştırılması. Eğitimde ve Psikolojide Ölçme ve Değerlendirme Dergisi 1(2), 65-71.

Duatepe, Asuman ve Çilesiz Şebnem (1999). Matematik Tutum Ölçeği Geliştirilmesi. Hacettepe Üniversitesi Ĕ̈itim Fakültesi Dergisi, 16(17), 45-52.

Gürefe, Nejla ve Kan, Adnan (2013). Öğretmen Adayları için Geometrik Cisimler Konusuna Yönelik Tutum Ölçeği Geliştirme Geçerlik ve Güvenirlik Çalışması, İlköğretim Online, 12(2), 356-366.

İnceoğlu, Metin (2004). Tutum Algı İletişsim (1. Baskı). Ankara: Elips Yayınları.

İlhan, Mustafa ve Çetin, Bayram (2014). Matematik Başarı Yönelimleri Ölçeği'nin Geliştirilmesi (MBYÖ): Geçerlik ve Güvenirlik Çalışması. International Online Journal of Educational Sciences, 6(3), 682-705.

Kabael, Tangül ve Tanışlı, Dilek (2010). Cebirsel Düşünme Sürecinde Örüntüden Fonksiyona Öğretim. İlkögretim Online 9(1) 213-228.

Kağıtçıbaşı, Çiğdem (2005). Yeni İnsan ve İnsanlar (10. Baskı). İstanbul: Evrim Yayınevi.

Kaplan, Abdullah ve Kaplan, Neslihan (2006). Ortaöğretim Öğrencilerinin Matematik Dersine Karş1 Tutumları. Journal of Qafqaz University (Social Science), 17 (1), 1-5.

Karasar, Niyazi (1999). Bilimsel Araştırma Yöntemi (9. Baskı). Ankara: Nobel Yayın Dăğıtım. 
Kurt, Hakan ve Ekici, Gülay (2013). Evaluating The Turkish Version of The Discipline Efficacy Scale (DES): Translation Adequacy and Factor Structure. Academic Journals, $8(15), 1207-1219$.

MEB (2009). İlkögretim Matematik Dersi 6 - 8. Sinıflar Öğretim Programı ve Kılavuzu. Ankara: MEB, Talim ve Terbiye Kurulu Başkanlığı.

MEB (2013). Ortaokul Matematik Dersi (5, 6, 7 ve 8. Sinıflar) Öğretim Programı. Ankara: MEB, Talim ve Terbiye Kurulu Başkanlığı.

MEB (2017). Matematik Dersi Öğretim Programı (İlkokul ve Ortaokul 1,2,3,4,5,6,7 ve 8. Sinıflar). Ankara: MEB, Talim ve Terbiye Kurulu Başkanlı̆̆ı.

Okur, Emel ve Özdilek, Şükran Yalçın (2012). Yapısal Eşitlik Modeli İle Geliştirilmiş Çevresel Tutum Ölçeği. İlkögrretim Online, 11(1), 85-94.

Öksüz, Cumali ve Ak, Şerife (2010). İlköğretim Okullarında Matematik Derslerinde Teknoloji Kullanım Düzeyini Belirleme Ölçeği Geçerlik ve Güvenirlik Çalışması. Elektronik Sosyal Bilimler Dergisi, 9(32), 372-383.

Önal, Nezih (2013). Ortaokul Öğrencilerinin Matematik Tutumlarına Yönelik Ölçek Geliştirme Çalışması. Elementary Education Online, 12(4), 938-948.

Palabıyık, Umut ve İspir, Oylum A. (2011). Örüntü Temelli Cebir Öğretiminin Öğrencilerin Cebirsel Düşünme Becerileri ve Matematiğe Karşı Tutumlarına Etkisi, Pamukkale Üniversitesi Ĕ̈itim Fakültesi Dergisi, 30(2), 111-123.

Palacios, Andres, Ariasi Victor ve Arias, Benito (2014). Attitudes Towards Mathematics: Construction and Validation of A Measurement Instrument. Revista de Psicodidáctica, 19(1), 67-91.

Somer, Oya, Korkmaz, Mediha, Dural, Seda ve Can, Seda (2009). Ölçme Eşdeğerliğinin Yapısal Eşitlik Modellemesi ve Madde Cevap Kuramı Kapsamında İncelenmesi. Türk Psikoloji Dergisi, 24(64), 61-75.

Sümer, Nebi (2000). Yapısal Eşitlik Modelleri: Temel Kavramlar ve Örnek Uygulamalar. Türk Psikoloji Yazlları, 3(6), 49-74.

Tavşancıl, Ezel (2010). Tutumların Ölçülmesi ve SPSS ile Veri Analizi (4. Baskı). Ankara: Nobel Yayın Dağıtım.

Tezbaşaran, Ata (1996). Likert Tipi Ölçek Gelişstirme Kllavuzu. Ankara: Türk Psikologlar Derneği Yayınları.

Van De Walle, John A., Karp, Karen S. ve Bay-Williams, Jennifer M. (2012). Illkokul ve Ortaokul Matematiği Gelişsimsel Yaklaşımla Öğretim. (Soner Durmuş, Çev.). Ankara: Nobel Yayın Dă̆ıtım

Yenilmez, Kürşat ve Avcu, Tevfik (2009). Altıncı Sınıf Öğrencilerinin Cebir Öğrenme Alanındaki Başarı Düzeyleri, Ahi Evran Üniversitesi Eğitim Fakültesi Dergisi, 10(2), $37-45$.

Yıldırım, Ali ve Şimşek, Hasan (2013). Sosyal Bilimlerde Nitel Araştırma Yöntemleri (9. Baskı). Ankara: Seçkin Yayıncılık. 


\section{EXTENDED ABSTRACT}

Purpose and Significance: The main purpose of this study is to develop a valid and reliable scale aimed at measuring the attitudes of secondary school students towards learning algebra. In this study, it is important for the students who take algebra lessons in secondary school to determine their attitudes towards the algebra and determine the most appropriate course processing and approaches for both the student and the other variables.

Methodology: In this study, the screening model was used. A survey is a survey study aimed at collecting data to identify specific characteristics of a group. The study group of the study consisted of 336 students who were randomly selected from 6th, 7th and 8th grade students in 5 different public schools in 2014-2015 academic year. Explicit factor analysis and confirmatory factor analysis were used in the scale with the basic components method. The Rotated Principal Component Analysis was used to evaluate the validity of the scale's construction. Pearson Correlation Coefficients were calculated in order to determine the relation between the total scores of the scale and the scores of the four subscales taken as criteria.

Results: In research, cronbach Alpha reliability coefficient of the Algebra Learning Area Attitude Scale (AAS) was ,96 before analysis and ,90 after the analysis. KMO test value of scale data was found ,949 and Bartlett test was found 9556,76 $(\mathrm{p}<, 05)$. The 28-item AAS obtained consists of four factors. The fit indices were calculated as $\chi^{2} / \mathrm{df}=1,83, \mathrm{GFI}=, 88, \mathrm{AGFI}=, 86$, $\mathrm{NFI}=, 95, \mathrm{NNFI}=, 97, \mathrm{CFI}=, 98 \mathrm{RMSEA}=, 05$ and $\mathrm{SRMR}=, 049$.

Discussion and Conclusion: The KMO test was 949 and the Bartlett test was 9556,759 $(\mathrm{p}<0.05)$. These two values indicate that the data set is appropriate for factor analysis. According to the findings obtained from the scale data, the cronbach alpha reliability coefficient is 90 . This value indicates that the scale has high reliability. In the last case, the total variance amount of 4 factors explained is $50,811 \%$. The load values of the factors after the exploratory and confirmatory factor analysis vary between ,365 and ,794. It is seen that the load values of the materials are at desired levels. The fit indices were calculated as $\chi^{2} / \mathrm{df}=1,83, \mathrm{GFI}=, 88$, $\mathrm{AGFI}=, 86, \mathrm{NFI}=, 95, \mathrm{NNFI}=, 97, \mathrm{CFI}=, 98 \mathrm{RMSEA}=, 05$ and $\mathrm{SRMR}=, 049$. As a result of the research, a valid and reliable attitude scale was developed. The NFI, NNFI and CFI indices correspond to a excellent fit of over, 95 , and a good fit above ,90. In this framework, it is seen that the NFI, NNFI and CFI values have excellent fit for the analysis performed. As a result, the scale consists of 4 factors and 28 items. It consists of 11 negative and 17 negative items from 28 items. 


\section{EK-1: Cebir Öğrenme Alanı Tutum Ölçeği (CTÖ) CEBİR ÖĞRENME ALANI TUTUM ÖLÇEĞİ ( CTÖ)}

Sevgili öğrenciler

$\mathrm{Bu}$ ölçek sizin matematikte cebir öğrenme alanına yönelik tutumunuzu ölçmek amacıyla hazırlanmıştır. Ölçekte verilen ifadelerin kesin bir cevabı yoktur. Maddelere vereceğiniz cevaplar sizin kendi düşüncenizi yansıtmaktadır. Lütfen bu maddeleri dikkatli bir şekilde okuyunuz ve belirtilen ifadeleri samimi bir şekilde sizin yaşamınızdaki anlam ve önemine göre karşısındaki puanlama cetvelinden duygu ve düşüncenizi en iyi yansıttığını düşündüğünüz seçeneği işaretleyiniz. Bu ölçekte doğru veya yanlış yoktur. Önemli olan sizin gerçek düşüncelerinizdir.

Lütfen her madde için yalnız bir seçeneği işaretleyiniz ve hiçbir maddeyi cevapsız bırakmayınız. İşaretlemelerinizi cümlelerin karşısındaki boşluklardan size en uygun olana (x) koyarak yapınız. Çalışmamıza sağladığınız katkı için teşekkür ederiz.
Cinsiyet
Kiz
( )
Erkek ( )
Sinif : 6. $\operatorname{Sinif}()$
7. $\operatorname{Sin} 1 f()$
8. $\operatorname{Sinif}()$

Maddeler

1 Günlük hayatta karşılaştığım problem durumlarını cebir ifadeleri kullanarak ifade etmeyi severim.

$2 \quad$ Cebirsel ifadeleri günlük hayatta kullanırım.

3 Cebir alanına ait konuları öğrenmek her zaman ilgimi çeker.

4 Cebirsel ifadeleri modellemek cebire karşı ilgimi arttırır.

5 İçimde cebire karşı aşırı bir öğrenme isteği var.

$\mathbf{6}$ Cebirin gerçek yaşama uygulaması olan bir alan olduğunu düşünürüm.

7 Verilen bir matematiksel modellemeyi cebirsel olarak ifade etmek beni heyecanlandirır.

8 Cebirle ilgili problemleri çözmek beni mutlu eder.

9 Sınavlarda soruları çözmeye cebire ait konulardan başlarım.

10 Cebirsel olarak verilmiş bir ifadeyle ilgili matematiksel cümle kurabilirim.

11 Verilen bir sözel ifadeyi cebirsel olarak ifade etmekte zorlanırım.

12 Cebir alanına ait konulara çalışmak problem çözme yeteneğimi arttırır.

13 Cebire ait konulara uğraşmak vakit kaybıdır.

14 Cebire ait hiçbir konu bana anlamlı gelmez.

15 Cebirsel ifadelerin matematikten çıkarılması gereklidir.

16 Matematik dersinde cebirsel ifadelerden sorumlu tutulmak istemem.

$1 \mathbf{1 7}$ Cebir ile ilgili problemler cebire karşı beni soğutur.

18 Cebire zorunda kaldığım için katlanırım.

19 Cebirsel ifadeleri yorumlamak hoşuma gidiyor.

20 Cebir matematiğin öğrenmesi zor alanlarından biridir.

21 Cebirsel ifadeleri bilmek veya bilmemek çok önemli değildir.

22 Cebir olmasaydı matematik bir şey kaybetmezdi.

23 Matematikte sayılar varken harflerin kullanılması bana saçma gelir.

24 Cebir konularının işlediği matematik derslerine katılmaktan zevk duyarım.

25 Cebirsel ifadeleri modellemek bana anlamsiz gelir.

26 Cebir sorularını çözememek beni korkutmaz.

27 Cebirle ilgili problemleri yapamamak beni endişelendirir.

$\mathbf{2 8}$ Cebir ile ilgili soruları çözememek beni umutsuzluğa düşürür. 